\title{
Metabolism of Di(ethylene glycol) [2-(2'-Hydroxyethoxy)ethanol] and Other Short Poly(ethylene glycol)s by Gram-negative Bacteria
}

\author{
By BARBARA A. PEARCE AND M. T. HEYDEMAN* \\ Department of Microbiology, University of Reading, London Road, Reading RG15AQ
}

(Received 25 September 1979)

\begin{abstract}
Obligately aerobic Gram-negative rod-shaped bacteria isolated from soil, sewage and river water grew using ethan-1,2-diol (MEG), 2-(2'-hydroxyethoxy)ethanol (DEG) or poly(ethylene glycol)s of up to 1500 molecular weight as sole carbon and energy source, though no single strain used the whole range. Only organisms that grew using MEG could grow on glycine or glycollate. An Acinetobacter strain(S8) degraded DEG and short poly(ethylene glycol)s by non-oxidative removal of ethylene oxide units as acetaldehyde, using a membrane-bound oxygen-sensitive enzyme of a novel type-DEG lyase - and leaving an unusable MEG residue. The $C_{2}$ units could be used for energy generation by the tricarboxylic acid cycle and for anabolic and anaplerotic functions via the glyoxylate cycle, key enzymes of which were induced by growth of the bacteria on DEG or short poly(ethylene glycol)s.
\end{abstract}

\section{INTRODUCTION}

Poly(ethylene glycol)s are linear homopolymers of ethylene oxide with a mean molecular weight of up to 10000 ; they have the general formula $\mathrm{H}\left(\mathrm{OCH}_{2} \mathrm{CH}_{2}\right)_{n} \mathrm{OH}$. They have found wide industrial application and are extensively used as non-ionic detergents. [Throughout this paper all members of the ethylene oxide polymer series are referred to as ethylene glycols (EGs). Other abbreviations used are mono(ethylene glycol), MEG; di(ethylene glycol), DEG; tri(ethylene glycol), TEG; tetra(ethylene glycol), TeEG; poly(ethylene glycol), PEG, sometimes with a numerical suffix denoting the approximate mean molecular weight, e.g. PEG 200.]

Many investigations into the biodegradation of EGs and non-ionic detergents have been concerned with assessing the ability of mixed cultures of sewage organisms to degrade these compounds aerobically (e.g. Lamb \& Jenkins, 1952; Mills \& Stack, 1953, 1954; Vath, 1964; Gerhold \& Malaney, 1966; Bunch \& Chambers, 1967) and whilst there have also been a number of reports of pure cultures of bacteria able to utilize MEG (Abeles \& Lee, 1961; Gaston \& Stadtman, 1963; Gonzalez et al., 1972; Claus \& Hempel, 1970) there are very few reports of bacteria able to utilize other EGs. De Ley \& Kersters (1964) reported the oxidation of DEG and TEG by Gluconobacter suboxydans but the most extensive study thus far appears to be that of Fincher \& Payne (1962) and Payne \& Todd (1966). These workers isolated from soil a bacterium that was able to grow on EGs up to PEG 400 and made a preliminary study of the mechanism of degradation. Haines \& Alexander (1975) isolated a PEG-utilizing strain of Pseudomonas aeruginosa, reported to use hydrolytic degradation to DEG and MEG. Jones \& Watson (1976) reported an Acinetobacter strain (SC25) utilizing MEG and PEG up to PEG 400 via glycolaldehyde, glyoxylate and the glycerate pathway, and (Watson \& Jones, 1977) Pseudomonas KW8 using DEG, TEG, PEG 200 or PEG 400, but not MEG. 
The purpose of the present study was to isolate from natural sources bacteria able to utilize various EGs as sole source of carbon and energy and to investigate the mechanism of attack on these compounds by a selected strain. The mechanism found differs from any reported elsewhere. A preliminary account of this work has been given (Whitehead \& Heydeman, 1975).

\section{METHODS}

Media. The chelated mineral base E medium of Owens \& Keddie (1969) was used for the isolation of EG-utilizing bacteria: mineral medium D of Macham \& Heydeman (1974) was used in all subsequent growth experiments. EG carbon sources were added to the mineral media at a final concentration of $0.2 \%$ $(\mathrm{w} / \mathrm{v})$ before sterilization by autoclaving for $15 \mathrm{~min}$ at $121{ }^{\circ} \mathrm{C}$. Other solutions used as carbon sources were sterilized with a Swinnex plastic syringe membrane filter (diam. $13 \mathrm{~mm}$, pore size $0 \cdot 2 \mu \mathrm{m}$ ). Solid media were prepared by the addition of $1.2 \%(\mathrm{w} / \mathrm{v})$ Difco agar to mineral base $\mathrm{E}$ with the various carbon sources.

Enrichment and isolation of bacteria. Bacteria were isolated, using standard procedures, from soil (Sonning Farm, University of Reading), effluent water from trickle filters (Reading Sewage Works) and water from the River Kennet. The isolates were characterized by standard methods (Cruickshank, 1965).

Determination of growth substrate specificity. The ranges of EGs and other compounds that would serve as carbon and energy sources were determined by streaking each isolate on plates containing mineral base $\mathrm{E}$ agar and the growth substrate $(0.1 \%, \mathrm{w} / \mathrm{v})$ and on control plates containing no added carbon source. When growth occurred, isolates were subcultured twice sequentially on the same medium.

Growth of bacterium S8. One of the isolates from soil, an Acinetobacter sp. designated bacterium S8, was grown at $30^{\circ} \mathrm{C}$ in $100 \mathrm{ml}$ medium D containing $0.2 \%$ (w/v) DEG, TEG or TeEG in $250 \mathrm{ml}$ conical flasks incubated in a Mickle water bath shaking at $120 \mathrm{~min}^{-1}$, throw $42 \mathrm{~mm}$. Growth was measured in an EEL long cell absorptiometer with a test tube adaptor and neutral density filter.

Measurement of EGs and degradation products. MEG, DEG, TEG and TeEG in culture supernatants were estimated by vapour phase chromatography using a Perkin-Elmer model F11 mark 2 gas chromatograph fitted with a flame ionization detector and coupled to a Vitatron UR 400/2 integrating chart recorder (carrier gas, $\mathrm{O}_{2}$-free $\mathrm{N}_{2}$ at a flow rate of $27 \mathrm{ml} \mathrm{min}^{-1}$; detector gases, air and $\mathrm{H}_{2}$ at pressures of 140 and 230 $\mathrm{kPa}$, respectively). For analysis of low molecular weight EGs a glass column, $1.83 \mathrm{~m}$ long $\times 2.5 \mathrm{~mm}$ internal diameter, packed with poly(tetrafluoroethylene) on Chromosorb G (60 to 80 mesh), was used at $230{ }^{\circ} \mathrm{C}$ (injection port temperature, $250^{\circ} \mathrm{C}$ ). Under these conditions the retention times observed were: MEG 0.75 min; DEG $2.4 \mathrm{~min}$; TEG $3.25 \mathrm{~min}$; TeEG $8.4 \mathrm{~min}$.

Degradation products were analysed in the same equipment using a Porapak Q (60 to 80 mesh) columnpacking at $180^{\circ} \mathrm{C}$. Retention times were: acetaldehyde $0.4 \mathrm{~min}$; ethanol $0.7 \mathrm{~min}$; acetic acid $1.9 \mathrm{~min}$; MEG $4 \cdot 15 \mathrm{~min}$.

Preparation of crude enzyme. Bacterium S8 $\left(50 \mathrm{mg}\right.$ equivalent dry wt $\mathrm{ml}^{-1}$ in $25 \mathrm{~mm}-\mathrm{Tris} / \mathrm{HCl}$ buffer $\mathrm{pH} 8.0$ ) was sensitized with $0.67 \mathrm{~mm}$ neutralized EDTA and incubated with $100 \mu \mathrm{g}$ lysozyme ml-1 (Goldschmidt \& Wyss, 1967) for $1 \mathrm{~h}$ at $30^{\circ} \mathrm{C}$. The resulting viscous preparation was incubated at $30^{\circ} \mathrm{C}$ for $40 \mathrm{~min}$ with $100 \mu \mathrm{g}$ DNAase $\mathrm{ml}^{-1}$ plus $100 \mu \mathrm{g}$ RNAase $\mathrm{ml}^{-1}$ plus $10 \mu \mathrm{g} \mathrm{MgCl}_{2} \mathrm{ml}^{-1}$, and then centrifuged at $7000 \mathrm{~g}$ for $10 \mathrm{~min}$. The pellet, consisting of bacterial envelope material, was washed once in $25 \mathrm{~mm}$-Tris/ $\mathrm{HCl}$ buffer pH 8.0 and then resuspended in the same buffer and treated with $0.25 \%(\mathrm{w} / \mathrm{v})$ sodium deoxycholate, added as a $10 \%(\mathrm{w} / \mathrm{v})$ aqueous solution, for $30 \mathrm{~min}$ at $3{ }^{\circ} \mathrm{C}$, stirring gently under an atmosphere of $\mathrm{N}_{2}$. After centrifugation at $52000 \mathrm{~g}$ for $30 \mathrm{~min}$ to remove insoluble material, the resultant solution was designated 'crude enzyme'. Although active material could be precipitated by ammonium sulphate, in the 0 to $20 \%$ and 30 to $50 \%$ saturated fractions, the total activity recovered was less than half of that at the start, and the specific activity was little, if any, higher.

Assay of enzyme activity. Substrate (final concentration $10 \mathrm{~mm}$ ) was added to enzyme preparation incubated at $25{ }^{\circ} \mathrm{C}$. Samples were taken for analysis, normally after 0,5 and $10 \mathrm{~min}$. Usually $0.5 \mathrm{ml}$ samples were heated rapidly to $85^{\circ} \mathrm{C}$, cooled, centrifuged to remove precipitated protein and then used for assay by vapour phase chromatography, but when volatile products were sought smaller samples $(0.9 \mu \mathrm{l})$ were injected directly into the gas chromatograph.

Assays of activity of enzymes of the tricarboxylic acid cycle and glyoxylate cycle. These were by standard procedures as follows: isocitrate dehydrogenase (NADP-linked) (EC 1.1.1.42) according to Shiio \& Ozaki (1968); 2-oxoglutarate dehydrogenase (EC 1.2.4.2) according to Mukherjee et al. (1965), under anaerobic conditions to avoid re-oxidation of NADH by oxidase activity in the extracts; succinyl-CoA synthetase (EC 6.2.1.5) according to Kaufman et al. (1953), using a standard curve for succinylhydroxamic acid prepared as described by Stadtman (1957); citrate synthase (EC 4.1.3.7) according to Srere et al. (1963); aconitate hydratase (EC 4.2.1.3) according to Pearce et al. (1969); succinate dehydrogenase (EC 
1.3.99.1) by a spectrophotometric modification of the method of Veeger et al. (1969), observing reduction of $50 \mu \mathrm{M}$-2,6-dichlorophenolindophenol as a decline in $A_{600}$ in the presence of $0.2 \mathrm{mM}-N$-methylphenazonium sulphate and 1.0 mM-potassium cyanide; fumarate hydratase (EC 4.2.1.2) according to Racker (1950); malate dehydrogenase (EC 1.1.1.37) according to Sottocasa et al. (1967); isocitrate lyase (EC 4.1.3.1) according to Dixon \& Kornberg (1959) but at pH 7.5; malate synthase (EC 4.1.3.2) according to Dixon \& Kornberg (1962).

\section{RESULTS}

Organisms isolated and their substrate ranges. Twenty strains of bacteria were obtained in pure culture. Their EG substrate ranges (Table 1) were strongly correlated with the source from which they had been isolated. Only isolates from sewage could grow on PEG 600 or above, and none grew on PEG 6000 . Both river isolates, but only one other, utilized MEG; these organisms were also the only ones capable of growth on glycine or glycollate as sole carbon and energy source, though all isolates grew on at least some of the intermediates of the tricarboxylic acid cycle or their related amino acids. No isolate used propan1,2-diol, acetaldehyde, glycolaldehyde or glyoxal for growth. Standard characterization tests (Buchanan \& Gibbons, 1974) showed organisms of group A to be of the genus Acinetobacter, and $\mathrm{C}$ to $\mathrm{E}$ to be Pseudomonas. Group B organisms, oxidase positive and with fermentative attack on glucose, were assigned to the genus Aeromonas, or, in one instance, a physiologically similar but peritrichously flagellate taxon.

Utilization of low molecular weight EGs by bacterium S8. During the growth of bacterium S8, an Acinetobacter strain of group A, on low molecular weight EGs there occurred a stepwise breakdown of the EG molecule with the successive appearance and disappearance of EGs sequentially lower in the series, until MEG accumulated as the ultimate product in concentrations approximately equimolar with the original substrate (Fig. 1). Throughout, there was about the same number of molecules of EGs present, when all sizes were summed.

Breakdown of other ethers. Organism S8 could grow on several alternative carbon sources related to DEG, TEG or TeEG, having the general formula $\mathrm{R} . \mathrm{O} . \mathrm{CH}_{2} \mathrm{CH}_{2} \mathrm{OH}$. There was always at least transient accumulation of $\mathrm{R} . \mathrm{OH}$. Degradation in this way was shown for 2-ethoxyethanol, 2-butoxyethanol, 2-(2'-butoxyethoxy)ethanol, and 2-(2'-methoxyethoxy)ethanol. The last of these stoicheiometrically yielded 2-methoxyethanol, which was not further degraded. 1-Methoxy-2-(2'-methoxyethoxy)ethane and 2-phenoxyethanol were also not degraded.

$D E G$ breakdown by deoxycholate-extracted crude enzyme preparations from bacterium $\mathrm{S} 8$. Disappearance of DEG and appearance of $\mathrm{C}_{2}$ products were dependent on the presence of undenatured enzyme, which was very sensitive to temperature, all enzymic activity being destroyed in $2 \mathrm{~min}$ at $55^{\circ} \mathrm{C}$. Of a range of possible cofactors tested, only cyanocobalamine and adenosylcobalamine ever showed significant ability to stimulate the rate of reaction, by up to $26 \%$, but this varied from one preparation to another; NAD, NADH, NADP, ATP, ADP, AMP or thiamin pyrophosphate had no effect. Oxygen had no effect on the rate of

\section{Table 1. Isolates and their substrate utilization patterns}

Bacteria were isolated as described in the text from soil (S), sewage effluent (E) or river water (R), characterized, and tested for growth on various EGs $(0.1 \%, \mathrm{w} / \mathrm{v})$ on mineral base $\mathrm{E}$ agar (Owens \& Keddie, 1969).

\begin{tabular}{|c|c|c|c|c|c|c|c|c|c|c|}
\hline \multirow[b]{2}{*}{ Group } & \multirow[b]{2}{*}{$\begin{array}{l}\text { No. of } \\
\text { isolates }\end{array}$} & \multirow[b]{2}{*}{ Source } & \multicolumn{8}{|c|}{ Growth on EGs } \\
\hline & & & MEG & DEG & $\begin{array}{c}\text { PEG } \\
200\end{array}$ & $\begin{array}{c}\text { PEG } \\
400\end{array}$ & $\begin{array}{c}\text { PEG } \\
600\end{array}$ & $\begin{array}{l}\text { PEG } \\
1000\end{array}$ & $\begin{array}{l}\text { PEG } \\
1500\end{array}$ & $\begin{array}{l}\text { PEG } \\
6000\end{array}$ \\
\hline A & 8 & $\mathrm{~S}$ & - & + & + & - & - & - & - & - \\
\hline B & 3 & $\mathbf{S}(1) ; \mathbf{R}(2)$ & + & + & + & + & - & - & - & - \\
\hline $\mathrm{C}$ & 2 & $\mathrm{~S}$ & - & - & + & + & - & - & - & - \\
\hline D & 5 & $\mathbf{E}$ & - & - & + & + & + & + & - & - \\
\hline $\mathrm{E}$ & 2 & $\mathrm{E}$ & - & - & - & + & + & + & + & - \\
\hline
\end{tabular}



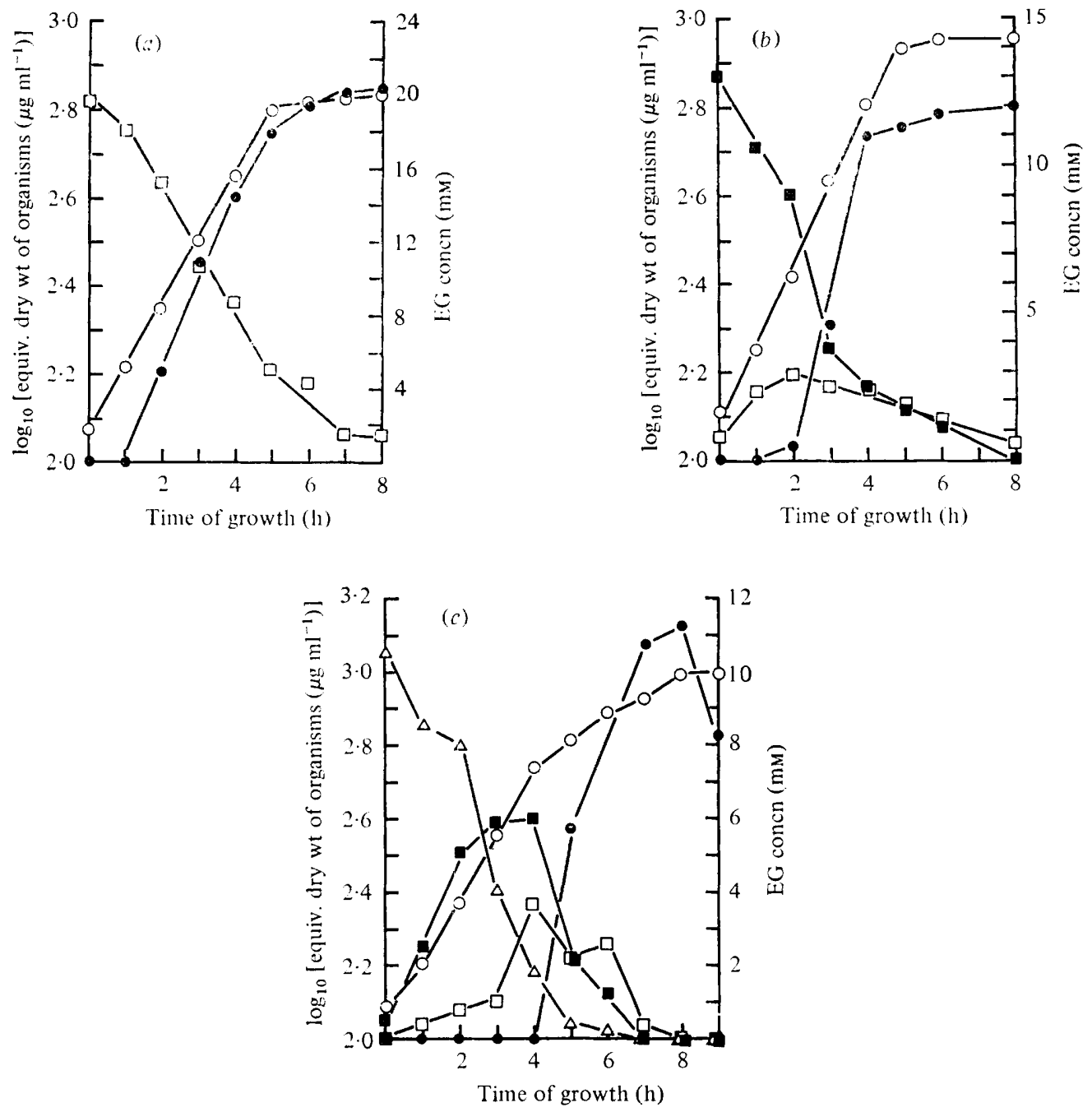

Fig. 1. Variation of substrate and end-product concentrations during growth of bacterium S8 on low molecular weight EGs. The original substrates added to the cultures were $(a)$ DEG, $(b)$ TEG and $(c)$ TeEG. Concentrations of EGs are shown by:, MEG; $\square$, DEG; $\square$, TEG; $\triangle$, TeEG. Organism concentration is shown by 0 .

DEG disappearance, though it increased the loss of activity of the enzyme preparation on storage. Most metal ions tested were without effect on the rate of reaction, but $\mathrm{Zn}^{2+}, \mathrm{Ag}^{+}$ and $\mathrm{Hg}^{2+}$ inhibited by 36 to $44 \%$ at $1 \mathrm{~mm}$ and by 64 to $100 \%$ at $10 \mathrm{~mm}$; $\mathrm{Cu}^{2+}$ inhibited by $50 \%$ at $10 \mathrm{~mm}$ but not at all at $1 \mathrm{~mm} ; \mathrm{Fe}^{2+}$ inhibited by $27 \%$ at $10 \mathrm{~mm}$ but stimulated by $21 \%$ at $1 \mathrm{~mm}$. Of inhibitors tested, at $1 \mathrm{~mm}$ final concentration, the following inhibited significantly: $p$-chloromercuribenzoate $(23 \%)$; hydroxylamine $(100 \%)$; EDTA $(21 \%)$; 1,10-phenanthroline $(25 \%)$.

Products of DEG breakdown. Concomitant with the disappearance of DEG, MEG was always produced in about equimolar amounts. Ethanol accounted for most of the remaining detectable material, though smaller amounts of acetic acid and traces of acetaldehyde were always present. The aldehyde trapping reagents semicarbazide or 2,4-dinitrophenylhydrazine strongly inhibited the reaction so that in the presence of an appreciable concentration 
Table 2. Tricarboxylic acid and glyoxylate cycle enzymes in bacterium S8

Crude ultrasonic extracts of bacterium S8 which had been grown on DEG or succinate were assayed by the procedures listed in Methods.

\begin{tabular}{|c|c|c|}
\hline \multirow[b]{3}{*}{ Enzyme } & \multicolumn{2}{|c|}{$\begin{array}{c}\text { Enzyme activity } \\
\text { [nmol substrate converted } \\
\left.\left.\min ^{-1}(\mathrm{mg} \text { protein })^{-1}\right)\right]\end{array}$} \\
\hline & \multicolumn{2}{|c|}{ Growth substrate } \\
\hline & DEG & Succinate \\
\hline $\begin{array}{l}\text { Isocitrate dehydrogenase } \\
\text { 2-Oxoglutarate dehydrogenase } \\
\text { Succinyl-CoA synthetase }\end{array}$ & $\begin{array}{r}282 \\
26 \\
26\end{array}$ & $\begin{array}{r}597 \\
66 \\
14\end{array}$ \\
\hline $\begin{array}{l}\text { Citrate synthase } \\
\text { Aconitate hydratase } \\
\text { Succinate dehydrogenase } \\
\text { Fumarate hydratase } \\
\text { Malate dehydrogenase }\end{array}$ & $\begin{array}{r}255 \\
935 \\
174 \\
374 \\
8638\end{array}$ & $\begin{array}{r}481 \\
1756 \\
188 \\
48 \\
7828\end{array}$ \\
\hline $\begin{array}{l}\text { Isocitrate lyase } \\
\text { Malate synthase }\end{array}$ & $\begin{array}{l}106 \\
384\end{array}$ & $\begin{array}{r}3 \\
222\end{array}$ \\
\hline
\end{tabular}

no products of any kind were detectable, but very low concentrations $(0.1 \mathrm{~mm})$ of semicarbazide were converted to the acetaldehyde compound. Acetaldehyde added to the standard assay system was rapidly converted to ethanol and smaller amounts of acetic acid.

Anaerobically, or in the presence of 1 mM-potassium cyanide, DEG disappeared as fast as aerobically, but no acetic acid was detectable among the products. Under these conditions added acetaldehyde was converted to ethanol.

Crude enzyme which had been dialysed for $1.5 \mathrm{~h}$ gave the usual products, but more slowly; after $3 \mathrm{~h}$ dialysis there was no activity, and none could be restored by the addition of NAD, NADH, FAD, supernatant fluid of boiled lysed bacterium S8, $\mathrm{FeSO}_{4}$ or cobalamines.

$K_{\mathrm{m}}$ for DEG. From the results of a series of experiments using different DEG concentrations, the Michaelis constant was evaluated, by the statistical procedure of Wilkinson (1961) using a BASIC computer program, as $15 \cdot 6 \pm 1 \cdot 6 \mathrm{~mm}$.

Enzymes of the tricarboxylic acid and glyoxylate cycles. The enzymes of both cycles were found in extracts of bacterium S8 that had been grown on DEG, but isocitrate lyase was. detectable only in trace amounts if the organism had been grown on succinate (Table 2).

\section{DISCUSSION}

The restricted EG ranges utilized as substrates by the isolates may be related to the variety of these compounds available in the environment. Bacteria from sewage, which contains EGs both free and in combination as waste products of industrial processes and domestic effluent, utilized mainly higher molecular weight EGs, though there was no isolate corresponding to that reported by Haines \& Alexander (1975) to grow on PEG 20000. River isolates utilized what could be considered to be the residue left by the sewage organisms. As it is unlikely that free EGs would occur in the soil it is difficult to envisage the natural role of this system in these bacteria.

Notably few isolates could utilize MEG, which accumulated in cultures of bacterium S8 growing on various low molecular weight EGs, as these were broken down by the stepwise removal of $\mathrm{C}_{2}$ units until only MEG remained.

The protein fraction extracted by deoxycholate from the envelopes of lysed bacterium S8 (referred to as crude enzyme) acted on DEG and the next few higher homologues in a 


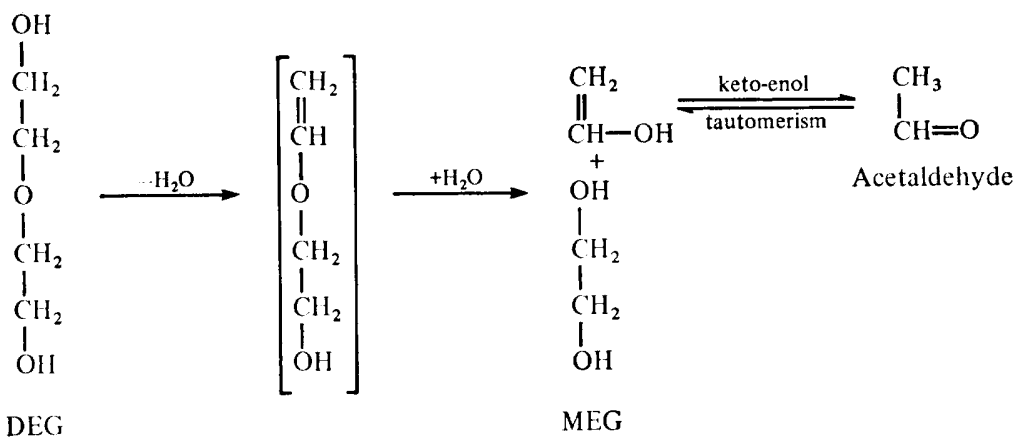

Fig. 2. Suggested mechanism for the conversion of di(ethylene glycol) (DEG) into mono(ethylene glycol) (MEG) and acetaldehyde. The vinyl ether intermediate, in brackets, is hypothetical.

similar way to the whole organism, degrading the molecules by removal of successive ethylene oxide units until MEG remained. The amount of this activity demonstrable in whole envelope material, and independent of oxygen or added cofactors, was sufficient to account for all activity of the organisms. Thus the crude enzyme is likely to be that responsible for DEG breakdown in vivo. Its lack of oxygen dependence sets it apart from the system described by Jones \& Watson (1976), and it differs from theirs and from those of Payne \& Todd (1966) and Haines \& Alexander (1975) in not being able to utilize MEG.

The units removed from DEG and homologues are at the oxidation level of acetaldehyde, and the name di(ethylene glycol) lyase is proposed for the enzyme or system responsible. A possible reaction sequence is that shown in Fig. 2. Although the overall effect is of an acetaldehyde-lyase, the two stages would represent an hydro-lyase and an hydrolase. Many enzymes are known which catalyse similar reactions to the dehydration suggested here. Three ether hydrolases are listed by the Commission on Biochemical Nomenclature (1978): EC 3.3.2.1, isochorismatase; EC 3.3.2.2, alkenyl-glycerophosphocholine hydrolase; and EC 3.3.2.3, epoxide hydratase. Each of these acts on what is essentially a highly-substituted vinyl ether. Thus although the overall effect of the reaction sequence depicted in Fig. 2 is quite novel, the stages by which it is attained can be related to known enzymic mechanisms. Crude enzyme - which was shown by polyacrylamide gel electrophoresis to contain at least 13 protein components - also contains alcohol and aldehyde dehydrogenase activities, to which may be attributed the final proportions of $\mathrm{C}_{2}$ products: some of the putative acetaldehyde is oxidized to acetic acid while the rest is reduced to ethanol. This is substantiated by the finding that added acetaldehyde gave the same $\mathrm{C}_{2}$ products as the nonMEG part of DEG under all conditions tested. The predominance of ethanol in these products, suggesting an endogenous reducing agent, remains unexplained.

The induction of isocitrate lyase and malate synthase by growth of organisms on DEG confirmed that assimilation of $\mathrm{C}_{2}$ units at the oxidation level of acetate was occurring: this is a further difference from the system in the Acinetobacter of Jones \& Watson (1976), which assimilates via glycolaldehyde and glyoxylate, using the glycerate pathway. The latter route of assimilation would explain the substrate range of the MEG-utilizing pseudomonads isolated in the present study.

Accumulated MEG, with a molecular structure and properties similar to those of DEG, inhibited breakdown of the latter. PEG may thus be degraded in Nature by the synergistic action of two or more strains of organisms. One yields, from PEG, a waste product, MEG, inhibitory to itself; the other utilizes the MEG and so facilitates the growth of its supplier. 


\section{REFERENCES}

Abeles, R. H. \& LeE, H. A., JR (1961). An intramolecular oxidation-reduction requiring a vitamin B12 coenzyme. Journal of Biological Chemistry 236, PC1-2.

Buchanan, R. E. \& Gibbons, N. E. (editors) (1974). Bergey's Manual of Determinative Bacteriology, 8th edn. Baltimore: Williams \& Wilkins.

Bunch, R. L. \& Chambers, C.W. (1967). A biodegradability test for organic compounds. Journal of the Water Pollution Control Federation 39, 181-187.

Claus, D. \& Hempel, W. (1970). Specific substrates for isolation and differentiation of Azotobacter vinelandii. Archiv für Mikrobiologie 73, 90-96.

Commission on Biochemical Nomenclature (1978). Enzyme Nomenclature. London: Academic Press.

Cruickshank, R. (1965). Medical Microbiology, 11th edn. Edinburgh \& London: E. \& S. Livingstone.

De Ley, J. \& Kersters, K. (1964). Oxidation of aliphatic glycols by acetic acid bacteria. Bacteriological Reviews 28, 164-180.

Dixon, G. H. \& Kornberg, H. L. (1959). Assay methods for key enzymes of the glyoxylate cycle. Biochemical Journal 72, 3P.

Dixon, G. H. \& Kornberg, H. L. (1962). Malate synthetase from baker's yeast. Methods in Enzymology 5, 633-637.

Fincher, E. L. \& PAYNe, W. J. (1962). Bacterial utilization of ether glycols. Applied Microbiology 10, 542-547.

Gaston, W. L. \& Stadtman, E. R. (1963). Fermentation of ethylene glycol by Clostridium glycolicum sp.n. Journal of Bacteriology 85, 356-362.

Gerhold, R. M. \& Malaney, G. W. (1966). Structural determinants in the oxidation of aliphatic compounds by activated sludge. Journal of the Water Pollution Control Federation 38, 562-579.

GoldsChMIDT, M. C. \& Wyss, O. (1967). The role of tris in EDTA toxicity and lysozyme lysis. Journal of General Microbiology 47, 421-431.

Gonzalez, C. F., Taber, W. A. \& Zeitoun, M. A. (1972). Biodegradation of ethylene glycol by a salt-requiring bacterium. Applied Microbiology 24, 911-919.

Haines, J. R. \& Alexander, M. (1975). Microbial degradation of polyethylene glycols. Applied Microbiology 29, 621-625.

Jones, N. \& Watson, G. K. (1976). Ethylene glycol and polyethylene glycol catabolism by a sewage bacterium. Biochemical Society Transactions 4, 891-892.

Kaufman, S., Gilvarg, C., Cori, O. \& Ochoa, S. (1953). Enzymatic oxidation of $\alpha$-ketoglutarate and coupled phosphorylation. Journal of Biological Chemistry 203, 869-888.

LAMB, C. B. \& Jenkins, G. F. (1952). B.O.D. of synthetic organic chemicals. Proceedings of the Seventh Industrial Waste Conference, Purdue University, pp. 328-339.

Macham, L. P. \& Heydeman, M. T. (1974). Pseudomonas aeruginosa mutants deficient in heptane oxidation. Journal of General Microbiology 85 , 77-84.

Mills, E. J., JR \& STack, V. T., JR (1953). Biological oxidation of synthetic organic chemicals. Proceedings of the Eighth Industrial Waste Conference, Purdue University, pp. 492-517.

Mills, E. J., JR \& STACK, V. T., JR (1954). Acclimation of microorganisms for the oxidation of pure organic chemicals. Proceedings of the Ninth Industrial Waste Conference, Purdue University, pp. 449-464.

Mukherjee, B. B., Matthews, J., Horney, D. L. \& REED, L. J. (1965). Resolution and reconstitution of the Escherichia coli $\alpha$-ketoglutarate dehydrogenase complex. Journal of Biological Chemistry 240, PC2268-2269.

OWEns, J. D. \& KeDdie, R. M. (1969). The nitrogen nutrition of soil and herbage coryneform bacteria. Journal of Applied Bacteriology 32, 338-347.

PAyne, W. J. \& TodD, R. L. (1966). Flavin-linked dehydrogenation of ether glycols by cell-free extracts of a soil bacterium. Journal of Bacteriology 91, 1533-1536.

Pearce, J., Leach, C. K. \& Carr, N. G. (1969). The incomplete tricarboxylic acid cycle in the bluegreen alga, Anabaena variabilis. Journal of General Microbiology 55, 371-378.

RACKER, E. (1950). Spectrophotometric measurements of the enzymic formation of fumaric and cis-aconitic acids. Biochimica et biophysica acta 4, 211-214.

ShiIO, I. \& OzaKI, H. (1968). Concerted inhibition of isocitrate dehydrogenase by glyoxalate plus oxalacetate. Journal of Biochemistry 64, 45-53.

Sottocasa, G. L., Kuylenstierna, B., ERnster, L. \& Bergstrand, A. (1967). Separation and some enzymic properties of the inner and outer membranes of rat liver mitochondria. Methods in Enzymology 10, 448-463.

Srere, P. A., Brazil, H. \& Gonen, L. (1963). The citrate condensing enzyme of pigeon breast muscle and moth flight muscle. Acta chemica scandinavica 17, S129-134.

Stadtman, E. R. (1957). Preparation and assay of acyl coenzyme A and other thiol esters; use of hydroxylamine. Methods in Enzymology 3, 931941.

VATH, C. A. (1964). Biodegradation of nonionics. Soap and Chemical Specialities 40 (2), 56-58, 182 and $40(3), 55-58,108$.

Veeger, C., Der Vantanian, D. V. \& Zeylemaker, W. P.. (1969). Succinate dehydrogenase. Methods in Enzymology 13, 81-90.

Watson, G. K. \& Jones, N. (1977). The biodegradation of polyethylene glycols by sewage bacteria. Water Research 11, 95-100.

Whitehead, B. A. \& Heydeman, M. T. (1975). The bacterial degradation of polyethylene glycols. Proceedings of the Society for General Microbiology 3, 5-6.

WILkInSON, G. N. (1961). Statistical estimations in enzyme kinetics. Biochemical Journal 80, 324-332. 